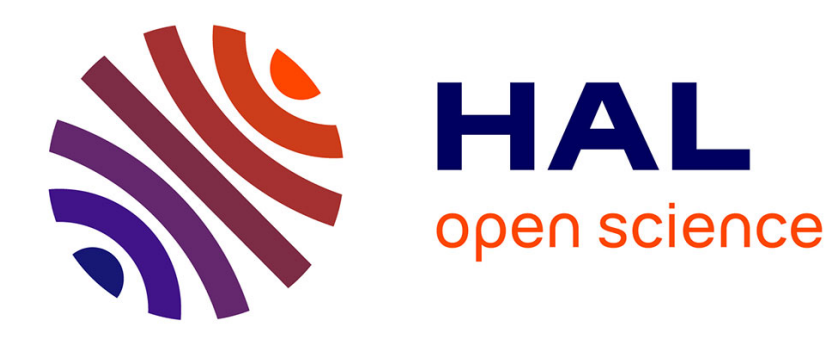

\title{
Dance in Walt Whitman's Leaves of Grass: Haptic Connectedness and Lyric Choreography
}

\author{
Adeline Chevrier-Bosseau
}

\section{To cite this version:}

Adeline Chevrier-Bosseau. Dance in Walt Whitman's Leaves of Grass: Haptic Connectedness and Lyric Choreography. Whitman, feuille à feuille, 2019. hal-02357544

HAL Id: hal-02357544

https://hal.uca.fr/hal-02357544

Submitted on 10 Nov 2019

HAL is a multi-disciplinary open access archive for the deposit and dissemination of scientific research documents, whether they are published or not. The documents may come from teaching and research institutions in France or abroad, or from public or private research centers.
L'archive ouverte pluridisciplinaire HAL, est destinée au dépôt et à la diffusion de documents scientifiques de niveau recherche, publiés ou non, émanant des établissements d'enseignement et de recherche français ou étrangers, des laboratoires publics ou privés. 


\title{
Dance in Walt Whitman's Leaves of Grass: Haptic Connectedness and Lyric Choreography
}

\author{
Adeline Chevrier-Bosseau, Université Clermont Auvergne
}

When reading what the pioneers of American dance wrote about their vision and plans for the renewal and rejuvenation of the art form, it is striking to see how omnipresent Walt Whitman, the self-professed "poet of the body" ( $L G$, p. 43$)$, is. Isadora Duncan, one of the greatest reformers of dance in the twentieth century, famously listed Walt Whitman as one of her "dance masters," along with Rousseau and Nietzsche, and defined herself as his "spiritual daughter." His poetry appears as a symbol of Americanness and a template for bold formal innovation in Ted Shawn's manifesto The American Ballet, published in 1926, as well as in Lincoln Kirstein's Dance, A Short History of Theatrical Dancing, published in $1970 .^{2}$ Whitman's celebration of the organic truth of the body found a particularly vibrant echo in the Denishawn school of dance, and in the works of all the founders of American modern dance, from the New Dance Group to Martha Graham, for whom the body was the ultimate locus of individual and collective truth. ${ }^{3}$ In "Whitman and Modern Dance," Joann Krieg delineates how Whitman's vision of the body, his views on questions of class and race, and his conception of American democracy resonated for the choreographers of the 1930s, particularly Helen Tamiris (who created her Walt Whitman Suite, inspired by Leaves of Grass, in 1934). ${ }^{4}$

While critics have investigated the impact of Walt Whitman's poetry on dancers, dance reformers and choreographers, the role and place of dance in Walt Whitman's Leaves of Grass remains widely overlooked. Yet it is one of the performing arts, along with opera and the theatre, which contributed to shaping Whitman's conception and performance of the lyric self. This paper examines how dance factors into Whitman's representation of the body and of the lyric self as an embodied, physical-sometimes athletic - being. I will begin by relating Whitman's evocation of dance in Leaves of Grass to the cultural and social significance of dance in mid-nineteenth-century America, where it functioned as a telltale sign of hierarchies of class. I will then turn to a close reading of "The Sleepers" ( $L G$, p. 356364), postulating that, in this poem, Whitman develops a unique form of lyric choreography, where the construction of the self as well as the lyric relation between the self and the addressee(s) or other selves are materialized and embodied as a dance.

\footnotetext{
${ }^{1}$ Isadora Duncan, My Life, NY \& London, Liveright Publishing, 2013, p. 21-22 and 65. Ruth L. Bohan's article entitled "'I Sing the Body Electric': Isadora Duncan, Whitman, and the Dance" investigates the influence of Walt Whitman on Isadora Duncan's life and art.

${ }^{2}$ Shawn delineates his conception of modern American dance through a comparison with Leaves of Grass: "the dance of America will be as seemingly formless as the poetry of Walt Whitman, and yet like Leaves of Grass it will be so big that it will encompass all forms. Its organization will be democratic, its fundamental principles, freedom and progress; its manifestation an institution of art expression through rhythmic, beautiful bodily movement, broader and more elastic than has ever yet been known" (Ted Shawn, The American Ballet, New York, Henry Holt \& Co, 1926, foreword). See also Lincoln Kirstein's Dance, A Short History of Theatrical Dancing, Westport, CT, Greenwood Press, 1970, p. 265.

${ }^{3}$ The Denishawn school of dance was founded by Ted Shawn and Ruth St Denis in 1915. The New Dance Group, founded in New York City in the early 1930s, was a group of leftwing artists (dancers, choreographers) who saw the body as an instrument of liberation, and sought to give a voice - or rather, an expression through the body-to the most oppressed and silenced, like the working-class, people of Jewish or African descent, and women.

${ }^{4}$ J. P. Krieg, "Whitman and Modern Dance,” p. 208-216.
} 


\section{Dance, class and the body in Leaves of Grass}

Bard or faun sounding his "barbaric yawp over the roofs of the world" ( $L G$, p. 77$)$, Whitman's lyric self roams through Leaves of Grass, brushing against a myriad bodies and engaging in various Dionysian dances. There are several moments in Leaves of Grass when the speaker explicitly represents himself dancing with other dancers in Dionysian enjoyment, as in "Native Moments" where he exclaims: "I am for those who believe in loose delights, I share the midnight orgies of young men, / I dance with the dancers and drink with the drinkers" ( $L G$, p. 94). ${ }^{5}$ In these scenes, dance-usually coupled with drinking and laughter in classic Dionysian fashion - is the physical expression of the exultation of the body. When social dance is depicted, it is always free and vigorous, as in the $15^{\text {th }}$ section of "Song of Myself": "The bugle calls in the ball-room, the gentlemen run for their partners, the dancers bow to each other" ( $L G$, p. 37). ${ }^{6}$ It is always represented as a popular form of entertainment, devoid of any rigid social etiquette, testifying to Whitman's affinity to the working class.

When Whitman wrote Leaves of Grass, social dancing was highly codified in the middle and upper classes. Between 1840 and 1860, as Ann Wagner notes, American culture became increasingly divided between highbrow and lowbrow, which greatly impacted dance as an art form and a social activity. ${ }^{7}$ Among the elite assemblies, dancing was to be respectful, elegant, and mindful of the proper etiquette as defined in the many dance manuals that kept rolling out of the printing presses at that time. In the rowdier popular balls, on the other hand, no etiquette was necessary. ${ }^{8}$ The first kind was above all social, and gaining entry to these balls was instrumental in someone's upward social mobility, whereas the second kind was merely entertainment for its own sake. ${ }^{9}$ Wagner further explains that only high society balls and assemblies, as well as attendance to "respectable" theatrical venues, were regulated by a set of etiquette rules - working-class amusements being wholly dismissed as improper and rude. ${ }^{10}$ The working-class danced mainly in informal settings such as barns, saloons, or outside, thus operating in the periphery of prescribed genteel amusements. While physical interactions were highly codified in upper-class assemblies, no such rules applied to the working-class, so that people were free to interact more spontaneously: if touching bare skin, using coarse language or dancing vigorously, holding one's partner firmly, were strictly prohibited in the upper-class, it was generally accepted in working-class balls. ${ }^{11}$ Studies by Ann Wagner, Kathy Peiss or Lawrence Levine have shown how such popular amusements were instrumental in creating American popular culture and enforcing a sense of belonging to a particular social class; attending venues in popular, lowbrow places like the Bowery theatre

\footnotetext{
${ }^{5}$ Section 3 of "Song of Myself" too represents the self's "satisfaction" through dance, laughter and song: "I am satisfied-I see, dance, laugh, sing" ( $L G$, p. 28). Dance is also one of the "joys" evoked in "Song of Joys": "Joy of sweet music, joy of the lighted ball-room and the dancers"; "O to have life henceforth a poem of new joys!/ To dance, clap hands, exult, shout, skip, leap, roll on, float on!” ( $L G$, p. 154, 155).

${ }^{6}$ Other examples include the "bull-dances" of section 33 of "Song of Myself" ( $L G$, p. 55), the "young men" dancing in "Our Old Feuillage ("Some of the younger men dance to the sound of the banjo or fiddle" $[L G, \mathrm{p}$. 147]), social dancing in the city in section 4 of "Song of the Broad-Axe" ("They fill their hour, the dancers dance, the musicians play for them", [LG, p. 159]), or the "wedding-dances" of section 12 of "Song of the Open Road" (LG, p. 132).

${ }^{7}$ Ann Louise Wagner, Adversaries of Dance: From the Puritans to the Present, Urbana and Chicago, University of Illinois Press, 1997. See also Lawrence Levine, Highbrow/Lowbrow, The Emergence of Cultural Hierarchy in America, Cambridge, MA, Harvard University Press, 1988.

${ }^{8}$ See A. L. Wagner, Adversaries of Dance, op. cit., p. 127-136. In addition to these advice manuals there were dance manuals, such as Charles Durang's Terpsichore, teaching American readers the new European dances, like the waltz or the polka, which reached America in the late 1840s (ibid., p. 144-145).

${ }^{9}$ Ibid, p. 107.

${ }^{10}$ Ibid, p. 151 .

${ }^{11}$ Ibid, p.170-173.
} 
or dancing outside the realm of genteel balls—as Whitman did—was thus a strong marker of class identity. ${ }^{12}$

Only among the working classes, then, was dance a vigorous and free affair as depicted in Whitman's poems. In the $7^{\text {th }}$ section of "Song of the Exposition," upper-class dancing is accordingly portrayed as crepuscular, "unhealthy" entertainment:

Away with old romance!

Away with novels, plots and plays of foreign courts,

Away with love-verses sugar'd in rhyme, the intrigues, amours of idlers,

Fitted for only banquets of the night where dancers to late music slide,

The unhealthy pleasures, extravagant dissipations of the few,

With perfumes, heat and wine, beneath the dazzling chandeliers. (LG, p. 170)

Where working-class dance scenes always evoke a rowdy assembly of young and healthy dancers, this dance scene is associated to the outdated, aristocratic Old World-and therefore unfit to Whitman's democratic America-, as is visible with the reference to "foreign courts" or "banquets." These aristocratic dancers are referred to as "idlers," as opposed to the workers dancing to the banjo in "Our Old Feuillage" for example, and the number of dancers is limited ("the unhealthy pleasures, extravagant dissipations of the few", my emphasis), contrary to working-class dance scenes. Whitman's use of the adjective "unhealthy" to refer to this form of upper-class entertainment is evocative in the context of nineteenth-century discourses on dance and health. Dance adversaries often deemed ballroom dancing "unhealthy" and harmful for the health of young ladies in particular, and identified the heat and late hours - as Whitman does in this section of "Song of the Exposition" — as the chief culprits of ill-health, along with promiscuity ${ }^{13}$. Dancing in balls, they thought, was harmful because it kept people up late, and the heat and proximity of all these bodies in a confined space was bound to foster the spread of contagious diseases. ${ }^{14}$ On the contrary, the spontaneous, unrestrained dancing of the lower classes - outdoors (as in "Our Old Feuillage" or "We Two Boys Together Clinging" for example) or in less stuffy ballrooms - was never viewed as unhealthy.

As many critics, like Jimmie Killinsgworth, Harold Aspiz, Michael Moon, or Tenney Nathanson, have noted, Whitman's interest in the body, the physical force and beauty of the human body, its kinetic and erotic expression, permeates Leaves of Grass. ${ }^{15}$ Killingsworth reminds us that Whitman reviewed Dr Edward Dixon's book Woman and Her Diseases-a plea for physical exercise as a remedy for many of the ailments afflicting the upper-classes

\footnotetext{
${ }^{12}$ See note 7 above. See also Kathy Peiss, Cheap Amusements: Working Women and Leisure in Turn-of-theCentury New York, Philadephia, Temple University Press, 1986, p. 100-104.

${ }^{13}$ This is also congruent with Whitman's interest in health issues and health policies. In his newly recovered series entitled "Manly Health and Training", published in the New York Atlas, Whitman urges sedentary men, students or clerks, to go out and exercise outdoors, for being confined indoors for hours is detrimental to their health. To the student he writes: "Let nothing divert you from your duty to your body. Up in the morning early! Habituate yourself to the brisk walk in the fresh air-to the exercise of pulling the oar-and to the loud declamation upon the hills, or along the shore." And he similarly encourages the clerk to exercise ("To you, clerk, literary man, sedentary person, man of fortune, idler, the same advice. Up! The world (perhaps you now look upon it with pallid and disgusted eyes) is full of zest and beauty for you, if you approach it in the right spirit!"). "Manly Health and Training", The New York Atlas, September 12, 1858, 1.

${ }^{14}$ A. L. Wagner, Adversaries of Dance, op. cit., p. 156-161. "The combination of overheated rooms and dancing to exhaustion, along with rich food consumed late at night and entry into chill air without proper clothes, regularly and inevitably, in the minds of many dance opponents, produced disease and death. Franklin Wilson coined the epitaph to this line of reasoning: 'The dance has proved to them (ladies) the herald of death, and the ball-room the gate of the grave"" (Ibid, p. 161).

${ }^{15}$ See H. Aspiz, Whitman and the Body Beautiful, T. Nathanson, Whitman's Presence: Body, Voice and Writing in Leaves of Grass, M. Moon, Disseminating Whitman: Revision and Corporeality in Leaves of Grass, J. Killingsworth, Whitman's Poetry of the Body; Sexuality, Politics, and the Text.
} 
(while people from the working class were thought to remain vigorous and healthy because they were physically active) - which, as Killinsgworth argues, most certainly influenced Whitman's positive outlook on physically active bodies. ${ }^{16}$ For Killingsworth, "Whitman's physicality implies a new understanding of beauty based on the health and vigor of the body." 17 And what he calls Whitman's "physical morality" would later in the century be echoed by the principles of François Delsarte, which were to become increasingly popular in the second half of the nineteenth century in America. ${ }^{18}$ For Delsarte and his disciples, the body doesn't lie, and each emotion is echoed and expressed through the body-which should never be repressed by moral or bourgeois conventions and should be free to unleash its expressive power. ${ }^{19}$

A similar class bias is perceptible when Whitman mentions foreign dances: in these poems, the waltz or the polka that were all the rage in genteel ballrooms in the second half of the nineteenth century, are replaced with less formal, free and energetic foreign dances, like the Irish jig or Spanish dances. ${ }^{20}$ When Whitman does evoke the waltz, as in section 4 of "Proud Music of the Storm," ( $L G$, p. 342-343), it is part of a cosmopolitan whirl of dances and music, where opera is heard along dance music and "the martial clang of cymbals," and where all religious dances are represented, from "dervishes," "the rapt religious dances of the Persians and Arabs," "modern Greeks dancing," to "wild old Corybantian" dances. The exultation of the body in these religious dances carries erotic undertones, which are emphasized by the cyclical, revolving rhythm of the section: the anaphoras "I see," "I hear" set the lines in a circular movement which always comes back to its beginning, thus breathing in considerable dynamism into the section as well as placing all these dances on the same level, with no hierarchy whatsoever. The section creates an image of a cosmopolitan whirl of dancing bodies, all united in this universal dance: the worshippers pray with their bodies, and through the music accompanying these dances; they offer their body in worship, an image that culminates in that of the last dancers evoked in the section, the Indian "bayaderes." The reference to the Indian "bayaderes" leaves no doubt as to the extent of Whitman's dance culture: appearing steadily in European ballets from the seventeenth century onwards, the character of the "bayadere" had become one of the great romantic heroines on the European stages, along with the characters of the Sylph and Giselle. ${ }^{21}$ Extracts from the ballet Le Dieu et la Bayadère, choreographed by Filippo Taglioni, were danced in America from the 1840s, in the wake of the American tour of the famous ballerina Fanny Elssler. The character of the bayadere is inspired by the Indian devadāsī ("servants of the gods," in Sanskrit) who were both courtesans, dancers and sacred servants of the temple. These characters, who arrive last in the enumeration of all the sacred dancers in the poem, crystallize this combination of sacredness and eroticism, the climactic exultation of the body in dance.

These sacred dances can also be read in the light of Whitman's primitivism, a desire to revert to a form of immediate, true expression, to connect to the truth of human nature and to

\footnotetext{
${ }^{16}$ J. Killingsworth, Whitman's Poetry of the Body, op. cit., p. 12.

${ }^{17}$ Ibid., p. 14.

${ }^{18}$ Ibid., p. 13.

${ }^{19}$ Steele MacKaye gave lectures in the 1870s popularizing Delsarte's theories among the American public; among his later disciples were all the pioneers of American dance, from Duncan to Graham, who all read Delsarte and incorporated his theory on the concordance between mind and body into their technique. See Nancy Lee Chalfa Ruyter, The Cultivation of Body and Mind in Nineteenth-Century American Delsartism, Wesport, CT, \& London, Greenwood Press, 1999. Ruyter notes that Longfellow and Edwin Forrest, whom Whitman much admired, were among the artists that were drawn to Delsartism (ibid., p. 17-29).

${ }^{20}$ See Whitman's references to "Irish ballads, merry jigs and dances" ("Proud Music of the Storm", section 3, $L G$, p. 341) and to "the Spanish dance with castanets in the chestnut shade" ("Salut au Monde", section 3, $L G$, p. 118).

${ }^{21}$ One of the first apparitions of this character dates back to Lully and Beauchamps' "Triomphe de 1'Amour" in 1681 .
} 
the truth of the body. ${ }^{22}$ This is especially true when Whitman evokes Native American dance or movement. The "Red Squaw" who appears fleetingly in "The Sleepers", for example, is primarily evoked through her physical appearance, with particular emphasis placed on her physical fitness: "Her step was free and elastic, and her voice sounded exquisitely as she spoke. / My mother look'd in delight and amazement at the stranger, / She look'd at the freshness of her tall-borne face and full and pliant limbs" (LG, p. 361). In "Our Old Feuillage", Native American dance appears as part of the great American pageant, "the acts, scenes, ways, persons, attitudes of these States," - Whitman's sweeping presentation of America and its inhabitants as a huge life-size drama - in the form of "the drama of the scalp-dance enacted with painted faces and guttural exclamations" ( $L G$, p. 94-95). The reference to "drama," and the pageant-like structure of the section that features Native American dance, recall the structure of nineteenth-century theatrical performances on American stages. These were organized in a succession of scenes where different forms of entertainment (dance, musical interludes, plays, ...) were offered to the spectators in the space of one evening. ${ }^{23}$ In that sense, Native American dance is transformed into a symbol of primitive Americanness, of a naturally embodied Americanness, moving freely and expressing itself physically- the starting point of the great American pageant. ${ }^{24}$

Dance in Leaves of Grass thus provides significant insight into Whitman's representation of contemporaneous issues of class and national identity. It also plays an important part in his representation of gender and eroticism. In that perspective, physical interactions in "The Sleepers" can be read as a dance in which the lyric self emerges as protean as ever, containing the proverbial Whitmanian multitudes.

\section{Lyric choreography in "The Sleepers"}

In Le Corps et sa danse, Daniel Sibony proposes that the ways the body carries itself, interacts with others and with the world around it, can all be translated in terms of dance:

le monde est de l'énergie qui danse: qui cherche au hasard des passages marquants, des mutations fécondes. [...] [L'énergie] dansante fait danser l'entre-deux, les formes passagères et transitoires; la danse traduit la masse corporelle en énergie, et l'énergie en masse. Le corps est une réserve d'énergie dansante, toute impliquée dans la naissance au "monde ", la naissance du monde, dont le danseur fait partie comme il fait partie de sa danse. ${ }^{25}$

\footnotetext{
${ }^{22}$ See for example Helen Carr, Inventing the American Primitive: Politics, Gender and the Representation of Native American Literary Traditions, 1789-1936, New York, New York University Press, 1996, p. 220-222; Yvor Winters, Primitivism and Decadence: A Study of American Experimental Poetry, New York, Haskell House, 1969, or W. Pannapacker, “'The Bricklayer shall lay me': Edward Carpenter, Walt Whitman, and Working-Class 'Comradeship'.”

${ }^{23}$ In The Portable Theater, American Literature and the Nineteenth-Century Stage (Baltimore and London, The Johns Hopkins University Press, 1999), Alan Ackerman delineates how performances on nineteenth-century American stages featured settings that were typically American, and, quoting Mary Ryan, explains that "between 1825 and 1880, [Americans] invented the modern parade." He further explains that "between these years the parade in America signified much about American democracy, documenting 'the development of such concepts as class, ethinicity and gender"' (p. 28). For further discussion of the relations between the stage and American culture in Whitman's time, see p. 1-41.

${ }^{24} \mathrm{~A}$ few decades later, the pioneers of American dance would also turn to Native American traditions and dances in the search of a primitive, true American movement, and would incorporate Native American dances into their own projects of choreographing America, their own mise en scène of the great American drama. One of the best examples is Martha Graham's Primitive Mysteries (1931). Graham also wanted to include an "Indian Girl" in Appalachian Spring (1944).

${ }^{25}$ Daniel Sibony, Le Corps et sa danse, Paris, Seuil, 1995, p. 94-95.
} 
The enumeration of dances in the $4^{\text {th }}$ section of "Proud Music of the Storm" is pure "énergie dansante," to use Sibony's terms, energy in motion: the circular rhythm takes the addressee in this dance around the globe with the speaker. A similar use of a circular rhythm, triggering a circular movement which draws the addressee in a whirl of moving, dancing bodies, can be found in "The Sleepers," ( $L G$, p. 356-364) in which Whitman develops a particular form of lyric choreography. In this poem, the speaker conjures visions of bodies in different states, sleeping bodies, dead bodies, bodies engaging in physical activities, and celebrates the beauty and strength of the human body - from the vigor of the "beautiful gigantic swimmer" and his white muscular body battered by the waves in section 3, to the "pliant limbs" of the "red squaw." The universal beauty of the human form, its health, are once again celebrated: "Perfect and clean the genitals previously jetting, and perfect and clean the womb cohering, / The head well-grown proportion'd and plumb, and the bowels and joints proportion'd and plumb" ( $L G$, p. 362). The poem reads like an endless whirl of bodies, conjured up and materialized through the lyric voice, in the circular movement and rhythm of an informal waltz, in which men and women waltz in and out, and the speaker-whose body's contours are frequently blurry, as his body merges with others' - appears in the middle of this whirl.

The body in "The Sleepers" is essentially protean and dynamic, capable of endless shifts in shape, appearance, and gender ("I am the actor, the actress, the voter, the politician" $L G$, p. 358). This protean quality intimately connects the lyric and dance. As Daniel Sibony argues, dance is an art form questioning the body's limits, an art form that, like the lyric, is essentially destined to an addressee - visible or invisible - and questions the origins and limits of selfhood: "la danse questionne toutes les façons qu'a le corps de se porter vers les frontières, des limites d'être, des mouvements originaux - qui mettent en jeu l'origine." 26 "The Sleepers" equally questions the limits of selfhood, since the protean speaker has the capacity not only to touch, but also to inhabit other bodies, to experience touch, physical contact from their own bodies. Not unlike dance which, according to Sibony, perpetually reverts to the origins of the body, by constantly reenacting the birth and rebirth of the self to the world, Whitman's poem dramatizes the origins of the body, with the image of the "newborn emerging from gates, and the dying emerging from gates" in the first section. The poem repeatedly crosses thresholds of selfhood and physical experience (being born, dying, sleeping and awakening, motion and stillness, the fusion of two bodies in sexual intercourse) and transcends the limits of the body to celebrate the universality of being, the vitality and energy of the human body and of the lyric. The lyric act of speaking to a faceless addressee becomes a dance to a faceless, universal public, in which the lyric self, at the center of this whirl of bodies that he bodies forth through language, becomes pure lyric energy-he becomes the dance:

I go from bedside to bedside, I sleep close with the other sleepers each in turn, I dream in my dream all the dreams of the other dreamers,

And I become the other dreamers.

I am a dance-play up there! The fit is whirling me fast! ( $L G$, p. 357)

In "Hair, Feet, Body and Connectedness in 'Song of Myself'," Taylor Hagood argues that one way of "understanding Whitman's complicated presentation of 'individuality vs democracy" lies in his depiction and positioning of body in 'Song of Myself." ${ }^{27} \mathrm{He}$ further contends that "head and feet" represent points of contact thanks to which the body can appear as a solidified entity or, on the contrary, as points between which the body dissolves:

\footnotetext{
${ }^{26}$ D. Sibony, Le Corps et sa danse, op. cit., p. 10.

${ }^{27}$ T. Hagood, "Hair, Feet, Body and Connectedness in 'Song of Myself'”, p. 25.
} 
These points (head and feet) may be the boundaries of a fluid and consolidated entity, or they may represent extremes that serve not to solidify but rather to fragment and disconnect the body and the self. Connectedness and consolidation embody Whitman's democratic ideal and are attainable only when the head and feet successfully make contact with each other and with the earth. ${ }^{28}$

In "The Sleepers," haptic connectedness is established in a similar way, through the hands of the speaker touching other selves, and his feet, evoked in the opening lines of the poem:

Stepping with light feet, swiftly and noiselessly stepping and stopping,

Bending with open eyes over the shut eyes of sleepers,

Wandering and confused, lost to myself, ill-assorted, contradictory,

Pausing, gazing, bending, and stopping.

The speaker's all-encompassing vision allows him to see every sleeper, to move from bed to bed, but vision is soon replaced by touch, from the soothing touch that helps the sleepers go back to sleep ("I pass my hands soothingly to and fro a few inches from them, / The restless sink in their beds, they fitfully sleep" [ $L G$, p. 357]) to erotic touch, when the speaker becomes a woman awaiting her lover and finally reunited with him in physical love ( $L G$, p. 358):

I am she who adorn'd herself and folded her hair expectantly,

My truant lover has come, and it is dark.

Double yourself and receive me darkness,

Receive me and my lover too, he will not let me go without him.

I roll myself upon you as upon a bed, I resign myself to the dusk.

He whom I call answers me and takes the place of my lover,

He rises with me silently from the bed.

Darkness, you are gentler than my lover, his flesh was sweaty and panting,

I feel the hot moisture yet that he left me.

A gender shift is performed in this passage, in which bodies merge, undercover of the engulfing darkness: the bodies of the lovers dissolve into one another, into darkness, and the only haptic memory left is the residual sweat of the male lover on the speaker's skin. ${ }^{29}$ Physicality is spectral, materialized in the remnants of a touch, these traces of "moisture," the haptic memory of flesh upon flesh. The contours of the speaker's body are fundamentally labile, moving from male to female, merging with the lover's body in the sexual experience, carrying the ghosts of previous incarnations within itself. ${ }^{30}$ In that sense the speaker (and speaker's body) of this poem is a perfect illustration of the lyric condition that can only be embodied through effects of voice. Between the two points of contact of the head and feet, the lyric self dissolves; he is not a dancer, but the dance itself as proclaimed at the end of section 1 , dancing energy in perpetual motion. This mode of haptic connectedness and this representation of the self as a blurry center of energy in between the two connecting points is also what connects dance and the lyric. This dichotomy between an elevation, a projection upward and outward and a firm grounding of the feet on the supporting ground is the essential animating principle of dance-whether one refers to the classical dance treaties by Noverre or

\footnotetext{
${ }^{28}$ Ibid., p. 25.

${ }^{29}$ J. Killingsworth notes that darkness in this passage is "permissive," allowing the homosexual initiation to take place, hidden by darkness and the gender shift (Whitman's Poetry of the Body, p. 19-20).

${ }^{30}$ For Jean-Michel Maulpoix, "le sujet lyrique est un sujet plein de voix tues qui sont comme les dépouilles de ses chimères et de ses potentialités" ("La quatrième personne du singulier, esquisse de portrait du sujet lyrique moderne," in Figures du sujet Lyrique, éd. Dominique Rabaté, Paris, Presses Universitaires de France, 1996, p. 159).
} 
Blasis $^{31}$, or the more contemporary conceptions of dance. It is also what defines the lyric; according to Jean-Michel Maulpoix, the lyric deploys itself between its starting point, the origin of speech, and this ideal of elevation. For Maulpoix, "il n'est rien de plus essentiel à la définition du lyrisme que l'idée d'élévation. Elle en est le principe actif." $32 \mathrm{He}$ adds: "le lyrisme regarde du côté de la source du poème (autant que son embouchure, ou de sa mise en voix), c'est-à-dire là où les énergies affluent et aspirent à se dépenser." ${ }^{33}$ Dance, like the lyric, can only thrive in this perpetual in-betweenness, between the anchoring ground and a higher point, in this spatial tension between two opposite points, and between two bodies, the lyric self's and the addressee's. If, following Maulpoix still, the lyric thrives in liminal spaces it is also the case for dance. ${ }^{34}$ For Daniel Sibony, "la danse déploie dans son espace la question de l'entre-deux-corps, le jeu des places et de leurs genèses, de leurs engendrements." "In "The Sleepers", the lyric self is perpetually "entre deux corps," moving between two bodies, two incarnations - ever liminal.

A few decades after the composition of "The Sleepers," French poet Stéphane Mallarmé would write about American dancer Loïe Fuller's performance that dance, like lyric poetry, is fleeting, mutable and evasive, evoking the "vibrant suspension" (suspens vibratoire) of a dance when the dancer is no longer a woman but a "sign," detached from the constraints of personality and individuality and free to be as protean as the lyric self. ${ }^{36}$ Commenting on Mallarmé's representation of the dance of Loïe Fuller, Mireille Ruppli and Sylvie ThorelCailleteau write:

Marquée par "l'inindividuel" ou "l'impersonnalité," elle (la danseuse) est désignée comme un "être dansant," "emblème, point quelqu'un"; par là s'indique comment, dans un même mouvement, le mot perd sa dimension numéraire et l'auteur sa présence élocutoire : le sol où s'appuie l'envol de la danseuse est aussi miroir, par lequel s'opère la transmutation d'un être en signe, de la même façon que l'installation des mots sur la page réalise l'abstraction de la personne du poète. ${ }^{37}$

The dance in "The Sleepers" articulates this Mallarmean "Entpersönnlichung" of the lyric self, which becomes impersonal, evading the limits of selfhood, and becoming open to all forms of mutations, shape-shifting and gender-shifting. ${ }^{38}$ This escape from personality may be one of the most modern aspects of Whitman's lyric.

Whitman's lyric self is therefore complex, at once embodied and physical and always attempting to merge into a greater, universal entity-personal and impersonal. The erotic experience is maybe one of the most telling examples of the lyric self's transgression of

\footnotetext{
${ }^{31}$ Jean-Georges Noverre, Lettres sur la danse, Paris, Éd. du Sandre, 2006 ; Charles Blasis, Traité élémentaire, théorie et pratique de l'art de la danse, Milan, J. Beati et A. Tenenti, 1820, ou Code complet de la danse, Paris, Audin, 1830.

32 Jean-Michel Maulpoix, Du Lyrisme, Paris, José Corti, 2000, p. 15.

${ }^{33}$ Ibid., p. 42.

34 "[L]e lyrisme semble avoir vocation aux lisières." Ibid., p. 349.

${ }^{35}$ D. Sibony, Le Corps et sa danse, op. cit., p. 10.

${ }^{36}$ Stéphane Mallarmé, "Autre Étude de Danse", Euvres Complètes, t. II, éd. Betrand Marchal, Paris, Gallimard, Bibliothèque de la Pléiade, 1998, p. 177. "Elle te livre à travers le voile dernier qui toujours reste, la nudité de tes concepts et silencieusement écrira ta vision à la façon d'un Signe, qu'elle est" (Mallarmé, "Ballets", op. cit., p. 174). Mallarmé famously said that dance was the theatrical embodiment of poetry ("la forme théâtrale de poésie par excellence,” Mallarmé, “Autre Étude de Danse”, op. cit., p. 175).

${ }^{37}$ Mireille Ruppli et Sylvie Throel-Cailleteau, Mallarmé, la grammaire et le grimoire, Genève, Droz, 2005, p. 158 .

38 This term was used by Hugo Friedrich to evoke the movement towards impersonality in Mallarmé's works. See Dominique Combe, “Aimé Césaire et la 'quête dramatique de l'identité': le Cahier d'un retour au pays natal”, in Le Sujet lyrique en question, éd. Dominique Rabaté, Joëlle de Sermet and Yves Vadé, Bordeaux, Presses Universitaires de Bordeaux, 1996, p. 188.
} 
gender and bodily limits. Many critics have remarked that when homosexual sexual acts are evoked in Leaves of Grass, a gender shift is performed. ${ }^{39}$ In section 11 of "Song of Myself," the speaker operates a similar gender shift to the one performed in "The Sleepers." In what Michael Moon has called a "grammatically-transvestite moment," dance is associated to this liberation from the limits of gender and selfhood, as the self "passes through feminine identity," and enters the scene dancing. "Dancing and laughing along the beach came the twenty-ninth bather, / The rest did not see her, but she saw them and loved them" (LG, p. 34). Examining dance in all its forms - social dance, but also ballet - can shed new light on the representation of lyric identity as fundamentally labile and on the performance of gender in Leaves of Grass. When considering the occurrences of dance cited above, it becomes apparent that Whitman frequently refers to men dancing, or uses gender-neutral terms such as "partners" or "dancers," which tones down the female presence in the dancing group. The "midnight orgies of young men" and the dance in "Native Moments," like the dance between the two men in "We two Boys Together Clinging" are unusual in the context of the nineteenth century, since dance writings (dance treaties, anti-dance treaties, dance manuals, press articles about dance...) overwhelmingly focused on female dancers. When male dancers were mentioned, the focus was mainly on their manners (or lack thereof), not on their dancing-whereas the elegance of women's dress, carriage and dance was the main focus. Men dancing-especially amongst themselves, such as the young men in "Our Old Feuillage"-were seldom represented. It is even more true when we consider ballet: in what was called "the age of the ballerina," the male dancer was almost invisible, self-effacing so as to leave the centre of the stage to the female dancer. What is striking, therefore, in the lyric choreography that is performed in "The Sleepers," is that it is modeled not on the ballerina's part - as it would be expected in the nineteenth-century context—but on the male dancers' parts in Romantic ballet.

Critics like Robert Faner or Carmen Skaggs have highlighted the importance of the stage and the performing arts in the formative years of the poet, who attended the theatre regularly. ${ }^{41}$ In fact, Whitman was a fixture at the New York theatres and opera houses. The great ballerinas of the 1840s Fanny Elssler and Augusta Maywood are mentioned in a letter sent to Whitman by Edward Mawson in 1885, and in his Reminiscence of the Bowery Theatre, Whitman recalls having seen Madame Céleste, one of the first famous French dancers to tour the country. ${ }^{42}$ In an October 1862 article published in the Brooklyn Standard, Whitman also refers to social dancing (which he actually engaged in) and a dance inspired by $L a$ Bayadere - thus confirming the fact that he did know the ballet. ${ }^{43}$ If we consider the character

\footnotetext{
${ }^{39}$ See J. Killingsworth, Whitman's Poetry of the Body, p. 19-23 ; T. Nathanson, Whitman's Presence, p. $102-106$.

${ }^{40}$ M. Moon, Disseminating Whitman, p. 42-44. See also $L G$, p. 855-863.

${ }^{41}$ See R. Faner, Whitman and Opera, and C. Skaggs, Overtones of Opera in American Literature from Whitman to Wharton.

42 The letter is dated August 17, 1885 and is available on the Walt Whitman Archive, https://whitmanarchive.org/biography/correspondence/tei/loc.03259.html. See also "The Old Bowery," in Walt Whitman's Complete Prose Works (1892), p. 1185-1192, available on the Walt Whitman Archive, https://whitmanarchive.org/archive1/works/completeprose/index.html. Madame Céleste made her American debut in 1827.

${ }^{43}$ The Brooklyn Standard, October 25, 1862, "Brooklyniana", $\mathrm{n}^{\circ} 38$, available on the Walt Whitman Archive, https://whitmanarchive.org/published/periodical/journalism/tei/per.00238.html :

We indulged in some impromptu quadrills, of which the "chassez" took each participant couple so far away from the other that they were like never to get back. We hopped like crows; we pivoted [pirouetted?] like Indian dervishes; we went through the trial dance of La Bayadere with wonderful vigor; and some one of our party came nigh dislocating his neck through volunteering to turn sumersaults like a circus fellow.

Given the date, Whitman probably refers to the 1830 version of the ballet, by Daniel Auber (music), Filippo Taglioni (choreography) and Eugene Scribe (libretto). The role of "La Bayadère" was created by Taglioni's daughter Marie on the Paris Opera stage. It was performed in New York City at the end of the 1830s in the Park
} 
of the Spanish dancer in Whitman's recently (re)discovered Life and Adventures of Jack Engle, the influence of the ballet on the poem becomes undeniable. Fanny Elssler, the Austrian ballerina who toured the country in the early 1840s, specialized in Spanish dancesla cachucha being her specialty. Elssler had a huge impact on American audiences, especially on men: Emerson mentions her in his journals, while Longfellow discusses her in his correspondence, even basing the character of Preciosa in The Spanish Student on Elssler. Given his admiration for strong, healthy, active bodies, Whitman would definitely have admired the graceful and vigorous dancing of ballerinas like Elssler, but it is also very likely that he should have been inspired by the male dancers who partnered Elssler or Maywood on stage.

In "The Sleepers" the central position of the self, coupled with an effacement of his body to the benefit of other bodies, and the circulation of his gaze echo the situation of the male dancer on stage. The representation of the speaker at the center of the poem, watching the "nimble ghosts," the whirl of bodies around him as he steps lightly across space, is common to many romantic ballets, where the lead male dancer often finds himself surrounded by whirling, dancing bodies. To wit the many scenes by the lakeside in Swan Lake where Siegfried watches the swans dance before engaging in a pas de deux with Odette, or the Shadows ("Le royaume des ombres") in the last act of La Bayadère, when Solor is deep in opium-induced sleep and the bayadères dance around him, or in the two ballets that were popular during Whitman's formative years, La Sylphide and Giselle. In the second act of Giselle, Hilarion and Albrecht also find themselves at the center of the whirl, when the wilis dance around them. In the second act of La Sylphide, James also adopts the same posture, when he is in the forest and all the sylphs dance around him. Those two scenes where the male dancer is surrounded by ethereal female dancers, the ghosts of abandoned maidens, may have provided inspiration for the speaker's vision of the "nimble ghosts" dancing around him in section 1.

The speaker, it should be noted, sees everyone, but is not looked at, except, one may surmise, in the sexual act depicted at the end of the first section, when the speaker becomes the woman waiting for her lover. This circulation of the gaze is typical of the situation of the male dancer on stage: his role is to partner the ballerina, to show her off, and his presence is deliberately upstaged by his female partners (this convention in classical ballet only changed in the late nineteenth century with Petipa, and even more in the following century, with Nijinsky and Nureev, who completely modified the role and our vision of male dancers). In the nineteenth century, the male dancer looked at his partners, but he was not meant to be looked at. The gaze was always directed to the female dancer. Dance critics have repeatedly shown how Romantic ballets were choreographed and staged for a principally male heterosexual audience, with a male heterosexual gaze in mind. The fact that Whitman models his lyric choreography on the male dancer's part - being in a central position, becoming the recipient of gaze and touch only when the self becomes feminized - is extremely significant and transgressive. First it attests to Whitman's anti-bourgeois perspective on ballet. Indeed, ballet critics of the nineteenth century often depicted male dancers negatively: they loved to see the female form displayed on stage, but shrunk from the spectacle of the male body. In 1838, Théophile Gautier wrote: "rien n'est plus abominable qu'un homme qui montre son cou rouge, ses grands bras musculeux, ses jambes aux mollets de suisse de paroisse, et toute sa lourde charpente virile ébranlée par les sauts et les pirouettes." 44 According to Ramsay Burt, "For the mid-nineteenth-century bourgeois ballet critic, vigorous and manly displays of

Theatre, the Bowery Theatre and the National Theatre. American ballerina Augusta Maywood made her debut as "La Bayadère" on the Philadelphia and New York stages before leaving America for Europe.

${ }^{44}$ Théophile Gautier, Euvres Complètes, Critique théâtrale, T1, éd. P. Berthier et F. Brunet, Paris, Honoré Champion, 2007, p. 487. 
dancing might sometimes have carried negative connotations of working-class entertainment." 45 That Whitman does not shy away from representing the lyric self as a male dancer can partly be explained by his affinity with the working class and his desire to represent the body as graceful because it is strong and vigorous, not according to traditionally bourgeois representations of the body. This construction of the lyric self as a male dancer is typical of Whitman's working-class erotics, since the strong, physically active body, is desirable $^{46}$, but also because of the fluidity in gender identification in the circulation of the erotic gaze: the passage through female identity in "The Sleepers" or the subversion of the male heterosexual gaze in Whitman's lyric choreography intimately associates Whitman's working-class erotics with the notion of mobility. As Jimmie Killingsworth notes in his study of "The Sleepers," sexual initiation is associated to the working-class. I would add that it is the working-class's inherent mobility (present in the name of the initiators, "the journeymen" ${ }^{47}$ ) which allows for the homosexual experience to take place-just as gender fluidity allows for the sexual encounter with a male partner to take place in the same poem, or in the episode of the "twenty-ninth bather" in "Song of Myself." This association of the working-class with some form of feminization and mobility is significant in its nineteenthcentury context: Michel Foucault, Elaine Showalter or Janet Beizer for example have shown that the working-class was equated to instability and mobility in the nineteenth century (whereas the bourgeois class was associated with stability), and thus to a form of social and sexual deviance and deviation. ${ }^{48}$ The affinity with working-class bodies and the deviation of the erotic gaze in Whitman's lyric choreography is a way to encode the homosexual experience, since for Ramsay Burt, looking at the male dancer in the context of nineteenthcentury ballet is necessarily a homoerotic act:

To enjoy the spectacle of men dancing is to be interested in men. Because there was no acknowledged distinction between ballet as aesthetic experience and ballet as erotic spectacle, ... the pleasures of watching men dancing became, in the mid-nineteenth-century, marred by anxieties about masculine identity. ${ }^{49}$

\footnotetext{
${ }^{45}$ Ramsay Burt, The Male Dancer, Bodies, Spectacle, Sexualities, NY \& London, Routledge, 1995, p. 27.

${ }^{46}$ In the previously quoted "Manly Health and Training" series, Whitman defines the "perfect body" has a body with "perfect blood-no morbid humors, no weakness, no impotency or deficiency or bad stuff in him; but all running over with animation and ardor, all marked by herculean strength, suppleness, a clear complexion, and the rich results (which follow such causes) of a laughing voice, a merry song morn and night, a sparkling eye, and an ever-happy soul!", The New York Atlas, September 12, 1858, 1. In other articles from this series, Whitman continues to emphasize the necessity for physical exercise outdoors and the beauty of the vigorously active man's body, while the sedentary middle-class or upper-class body is perceived as weaker and more prone to the above quoted "morbid humors".

${ }^{47}$ According to Killingworth, "'Journeymen' signifies members of the working class, but a special breedskilled, accomplished workers, special companions for the sexual neophyte, from whom 'they hide nothing'" (Whitman's Poetry of the Body, p. 17-18).

${ }^{48}$ See Michel Foucault, Histoire de la folie à l'âge classique, Paris, Gallimard, 1976; Elaine Showalter, The Female Malady: Women, Madness and English Culture, 1830-1980, New York, Pantheon Books, 1985; Janet Beizer, Ventriloquized Bodies, Narratives of Hysteria in Ninetenth-century France, Ithaca, Cornell University Press, 1994. Commenting on an excerpt from Michèle Ouerd's Leçons sur l'hystérie virile ("la classe ouvrière est imaginée dans le grand corps social de la République fin de siècle comme l'utérus migrateur de l'hystérique traditionnelle" [Paris, Le Sycomore, 1984, p. 27]), Beizer writes: "By the latter part of the century the hysteria label was an attempt to pin down or arrest the upwardly mobile desires of various social outcasts. These marginalized elements come to include not only those perceived as inferior by sex or by class, but by race as well. (...) Typed as unsettled, undisciplined, and unstable, the unempowered classes and races are effeminized, and hystericized by analogy to woman" (Beizer, op. cit., p. 50, ellipsis mine).

${ }^{49}$ J. Burt, The Male Dancer, Bodies, Spectacle, Sexualities, op. cit., p. 28.
} 
For Whitman,"being a dance" ("I am a dance" [LG, p. 357]), I would eventually argue, equals being a protean lyric self, performing endless shifts in shape, appearance, gender and social class, a self, connected through the feet and the head to the two cardinal points of the earth and the sky, the beginning and the end of the poem, but ever-mutable in-betweenembodied, personal and impersonal at the same time. The lyric is the expression of a desire to go beyond the borders of selfhood, to venture forth in the world through language, a desire which also applies to dance. Just as nothing "happens" in a poem but the birth of the lyric self to the world, the projection of the lyric utterance, nothing happens in a dance but the body's awakening and its expression, the projection outward of the body's energies. Languagephysical or verbal - is energy for Whitman, and always celebrates, performs, the vitality and glory of the human body and human experience. If Whitman "make(s) words dance," he also creates this unique lyric choreography for a self whose physical contours appear very strongly, and then dissipate. ${ }^{50}$ In his poems, dance appears as a liberating physical experience, allowing the self to escape personality and simultaneously, if paradoxically, be extremely physical and embodied. Whitman's poetry, through and as dance, thus challenges nineteenth-century bourgeois expectations regarding class and gender and creates a dynamics of mutation and movement which allows for the homoerotic experience to take place surreptitiously, among the many shifts in bodies, gender and perspectives.

\footnotetext{
${ }^{50}$ In An American Primer, Whitman writes: "A perfect writer would make words sing, dance, kiss, do the male an female act, bear children, weep, bleed rage, stab, steal, fire cannon, steer ships, sack cities, charge with cavalry or infantry, or, do anything that man or woman or the natural powers can do" (p. 16).
} 